\title{
Editorial \\ On race, racial profiling and states of mind(lessness)
}

Latino Studies (2010) 8, 149-155. doi:10.1057/lst.2010.22

The mood here is not anti-immigrant. It is anti-Mexican. The racial profiling law has little to do with legalities; it is about the expressed targeting of red-brown Indigenous peoples ...

(Roberto Dr. Cintli Rodriguez, 2010)

If you think education is expensive, try ignorance.

(Derek Bok, Former President, Harvard University)

As the present issue of Latino Studies goes to press, I cannot help but share with you my immense anxiety and incredulity as I contemplate the state of affairs in our society with reference to the realities of the daily lives and struggles confronting Latino/a communities across the country and their relations with other groups. It is difficult to believe that in 2010, we are still being consigned to situations in which our very lives as human beings and citizens - whether full citizens or citizens-in-the-making - are being questioned. The implicit threats and explicit consequences that the passage of SB 1070 on 23rd April in Arizona poses to the well-being and lives of Latino/as - to say nothing of our nation's humanity - cannot be underestimated. Can one really believe, as polls try to convince us, that large numbers of Americans across the country are so in favor of Arizona's regressive initiatives, as to set in motion a legally sanctioned policy of blatant racial and ethnic profiling of Latino/as, with the sole aim of challenging their right to belonging to the polity and society? What, then, should we make of the findings in the fact sheet released on 29th April, by the Pew Research Center (2010), of its survey taken just before the passage of Arizona's SB 1070, that found that, “More Americans believe that Hispanics are the targets of a lot of discrimination in American society than say the same about any other major racial or ethnic group"? And what is the attitude and the role of the mainstream media in this context of blatant expressions of hatred and escalating fear mongering?

One of the unexpected consequences of current developments in Arizona has been the open questioning by some police officers of their added responsibility to 
make on-the-spot decisions about who to stop and question - and perhaps arrest in the midst of their other obligations. Their response should remind us of an aspect of the aftermath of the 1897 Plessy v. Ferguson case, when the railroad companies were similarly not thrilled about requiring their conductors to make comparable snap judgments as to the racial whiteness or non-whiteness of their passengers. If we thought that those days were far into the past, the Arizona case like the attempts elsewhere, including the state of Rhode Island, where a legislator, apparently impressed by the mindless racism of Arizona's legislature, could not resist a rush to copycat legislation - is a painful reminder that the nation's racial history and practices are alive and well today.

Although this issue of Latino Studies was already in the works, Arizona's SB 1070 has made its theme even more poignant, directing our attention to the continued significance of race, racial profiling, and states of mind(lessness) in all their complexity, bringing to the fore the ongoing slippery terrain of racial and color factors within the Latino community, and their import for national and transnational race relations. Added to the recent passage of Arizona's antiintellectual Ethnic Studies law (HB 2281) - which both bans the teaching of the history and culture of Latino/as in the United States, and allows the censoring of previously approved text books - the potential short and long-term impact of SB 1070 can be devastating both to our communities, regardless of status, and to all Latino/as' ability to affirm their right to have rights in the society in which they live. Shortly before Arizona Governor Brewer signed HB 2281 into law on 12 May 2010, six UN human rights experts released a statement condemning the measure, and expressing their concern: "All people have the right to learn about their own cultural and linguistic heritage, they said" (Connors, 2010).

The egregious disregard - and, indeed, erasure - of Latino/as' historical and ongoing contributions to this country is now officially condoned in Arizona the next step in the ongoing escalation of laws and policies that increasingly criminalize and persecute Latino/as - supported by the actions, both big and small, of mindless citizens in this society. This Ethnic Studies law, for example, directly attacks the Tucson Unified School District program, which, as Connors (ibid.) describes,

offers specialized courses in African-American, Mexican-American and Native-American studies that focus on history and literature and include information about the influence of a particular ethnic group.

For example, in the Mexican-American Studies program, an American history course explores the role of Hispanics in the Vietnam War, and a literature course emphasizes Latino authors.

The repercussions of this Ethnic Studies bill, of course, go far beyond the Tucson School District program it is designed to target. For, it openly and officially 
condones past and present willful acts of ignorance by US citizens, such as that of the acclaimed documentary maker, Ken Burns, in 2007. That year, Burns was publicly forced by the Defend the Honor campaign to incorporate the honorable and courageous military service of Latino/as, many of whom sacrificed their lives for this nation, into his 14 part series on WWII, although, ultimately, Burns did so only tangentially. ${ }^{1}$ Burns' egregious act of erasure came precisely during the demonstrations against the 2005 Sensenbrenner congressional bill, which led millions to the nation's streets to protest its patent and widely disseminated criminalization of Latino/as. Again, I ask, what role is the mainstream media playing in the ongoing escalation of persecution against Latino/as and the simultaneous denial of their significant contributions to this nation?

Insofar as this society continues to actively support the erasure, official and otherwise, of Latino/as' presence, and seemingly endorses its willful ignorance about their ongoing contributions, should we continue to be surprised that all Latino/as, regardless of status, are increasingly perceived to be (potential or actual) "illegals" and/or criminal/lawbreakers? Should we wonder why it is that the lives of Latino/as are considered to be so disposable that they are now the largest incarcerated minority group in private sector, for-profit federal prisons? Should we stop asking why it is that when it comes to Latino/as, there is a clear gap between this society's insistence on "family values," and its perception of Latino/a families as being deemed so worthless that it allows inhumane detentions and deportations to tear Latino/a children from their parents? Should we stop thinking about the fact that 14-year-old Latino youth can just be murdered at any time, whether they are on US or Mexican soil, by the US Border Patrol - as Sergio Adrian Hernández was, on 28 May 2010, ostensibly in the name of national security? ${ }^{2}$

Clearly ignorance - willful or otherwise - is always dangerous, and has serious consequences for our own humanity, as well as for our society's well-being. As former Harvard University President, Derik Bok, once warned, "if you think education is expensive, try ignorance."

In the lead article of this Issue, The Power of Racial Scripts: What the History of Mexican Immigration to the United States Teaches Us About Race, Natalia Molina takes us into the realm of the historical uses and abuses of homogenizing racial discourses in the legislation against people of Mexican descent, particularly in the aftermath of the passage of the 1924 Immigration Act. She shows how the racial scripts that structured the historical experiences of Blacks and other people of color, were also used to shape both the meaning of the term "Mexican" and the social experiences of people of Mexican descent - and describes how it both went beyond and simultaneously reflected and refracted the bifurcated Black/ White racial paradigm. In the process, willingly or not, Mexicans in the United States were read in relation to and against the experiences of African Americans and other minorities with complex consequences, not the least of which was how
1 The campaign is well documented on http:// defendthehonor. org/, cf. also my editorial in Latino Studies 5(2) (2007).

2 Ironically, Sergio Hernández died, exactly 13 years to the week, after the National Guard murdered with impunity, another young Latino, the shepherd, Ezequiel Hernández, on 20 May 1977 (cf. Morones, 2010). 
Mexicans should relate to - or distance themselves from - the least favored group, racially speaking, in the United States.

Julie A. Dowling and C. Alison Newby continue this discussion of the consequences of US racial discourses for Latino/as and the meaning of blackness in the US context. Their article, Far From Miami: Afro-Cuban Encounters with Mexicans in the US Southwest, explores inter- and intra-Latino relations and the import of racial factors, as two Latino/a groups with no prior history of proximity or co-existence, are compelled to work through new and old realities, including that of the persistence of race in shaping their lives in the United States. The authors argue that Afro Cubans look to the history and experience of the Cuban diaspora in Miami, as a comfort symbol of their right to be in the United States. At the same time, Afro Cubans also perceive blackness as an affirmation of US citizenship and belonging, however tenuous it might be, and thus, in the specific context of the Mexican southwest, they come to experience their own blackness as a protective shield. In contrast, insofar as Mexicans bear the "physical marker of illegality ... Brownness", they are perceived as perpetual foreigners in their own land, paradoxically, in a region in which the lives of people of Mexican descent have long been rooted.

Jossiana Arroyo's anthropological discussion of the "Roots" or the Virtualities of Racial Imaginaries in Puerto Rico and the Diaspora, reminds us once again of Puerto Rico's special place within Latino and US race relations, and the varied impact and consequences of our nation's Black/White paradigm for Puerto Ricans' daily lives, both at home on the island and in the diaspora. Taking as her point of departure the debates stemming from the Banco Popular video, "Raíces"/(Roots), on Puerto Rican bomba and plena rhythms, she analyzes the meaning and social value of blackness in Puerto Rican racial imaginaries. Ultimately, Arroyo argues, "roots are also routes that articulate an understanding of blackness, race, and racialization in contemporary Caribbean/ US global circuits." Thus rendered, Puerto Rican imaginaries and discourses on race and blackness, within the broader discussion of Latino racial imaginaries, become manifest. Presenting a nuanced analysis of the discussion of blackness on the island and in two different regions of the United States, Arroyo discusses the ways that in the diaspora, the musical groups and youth are embracing blackness as a way of reviving and building on old alliances, intellectual, political, and cultural. She notes that these were destroyed by the national histories that have long emphasized hegemonic whiteness or Hispanicity in the island societies of the Caribbean, thus distancing themselves from the meaning of blackness symbolized by Haiti.

Indeed, while more Latino/as may be choosing to embrace their blackness, as the articles by Dowling and Newby and Arroyo suggest, the complex ongoing relevance of the ideology of whiteness in Latino/as' perceptions of race should not be underestimated. For example, a June 2010 study published in the American Sociological Review (Frank et al, 2010) shows that in the absence 
of the "some other race" option "in the New Immigrant Survey, more than three-quarters of respondents (79 per cent) identified themselves as White, regardless of their skin color," (Treviño, 2010). While the researchers argue that Latino/as are trying to pass because they recognize the "advantages of whiteness," syndicated journalist and local public radio commentator, Melissa Treviño, publisher of Latina Lista, "begs to differ." In a recent article titled "For Latinos 'being White' is more of a state of mind than skin tone," in response to the study by Frank et al, Treviño argues that, "When it comes to the US Latino population, skin tone is secondary to mindset." In contrast to Arroyo's argument however, Treviño underscores her understanding of the complexity of US Latino/as' relation to race, emphasizing, "Unless a family was Afro-Latino, choosing the 'Black' descriptor normally wouldn't even enter someone's mind." Noting that, "Most US Latinos, especially in the Southwest, don't see skin color," she explains that when it comes to race, "state of mind," rather than skin color, is the key to understanding Latino/as' racial self-definitions.

In his article, Cosa de Blancos: Cuban-American whiteness and the Afro-Cuban Occupied House, Antonio Lopez directly addresses the question of states of mind - specifically from the perspective of the role that memory plays in (White) Cuban-American writers' autobiographical (re)creations of their return to Cuba, to their former lives, and the properties their exiled families left behind. Now inhabited by their less privileged former (Brown) servants, their encounter with their past experience serves to unmask the permanence of the constitutive element of their Cuban-American experience - White privilege. In his article, Lopez transports us into another world of historical exceptionalism, if only in the sense of contact with the United States and the specificities of immigration and reception in the United States. What is particularly insightful in his article is what we might appropriately characterize as the unintended results of migration, the return (whether temporary or imagined) to the source, and the unmistakable racial dimensions, which point to unexpected and non-traditional understandings of national narratives about race and race relations.

Undoubtedly, states of mind (or mindlessness, as the case may be) are also what can lead to sometimes endless discussions and (re)interpretations of both art, including murals, and (skin) color. Consider for example, the effects of Arizona Councilman Steve Blair's mindless disregard for diversity, a word he insists he "can't stand." Discussing a school wall mural in his hometown of Prescott, Arizona, Blair recently asserted that "Art is in the eye of the beholder, but I say [the mural] looks like graffiti in L.A." And thus, he asked why "the biggest picture on that building" is depicted "as a Black person." It seems that his own state of mind(lessness) does not allow Blair to distinguish Mexicans from Blacks, for, as a school official explained, "The 'Black guy' in the mural is based on a student of Mexican descent." Meanwhile, insofar as in Prescott, Arizona, states of mind(lessness), apparently, can create considerable "racial 
confusion," the school's principal, Jeff Lane, decided to take these matters of perception into his own hands, asking the mural artists "to remove some shadowing that made the faces darker than they are" (Alfano, 2010).

How racial perceptions, ideologies, states of mind, are played out in people's daily lives in the real world, as the various examples presented above suggest, have very real consequences for relations between both individuals and communities. Jorge Capetillo-Ponce's article, Black-Latino/a Relations in Boston: Two Trends of Collective Identification takes us into the concrete universe of the relations between these two communities in Boston. It is a city where, despite a history of relations between leaders and spokespersons from both sides, day-to-day interactions can take on a life of their own. Moreover, all the goodwill notwithstanding, this has the potential of seriously challenging collaborative efforts and cooperative endeavors. Capetillo-Ponce's article suggests that in the wake of crisis, while continuing, rather than episodic, dialog is clearly preferred, the politics of language and national and foreign blackness can disrupt efforts at cooperation in unexpected ways.

Finally, in this Issue, we also include our yearly section, Reflexiones Pedagógicas, featuring Ralph Armbruster's essay, A People's History of Los Angeles: Teaching the Brown/Black Metropolis - Is Another Los Angeles Possible? Describing his approach to the teaching of the urban Black and Latino experiences in Los Angeles, Armbruster provides a useful reminder of the importance of contextualizing our nation's political and cultural realities in our classrooms.

Taken together, these essays offer us the opportunity for critical reflection and analysis of the meanings of race and blackness within and beyond the Latino/a community. They also serve to alert us to the terrible losses and devastations that the nation's refashioned racism can wreak today on the health of the body politic.

In this context, there is one issue that must be confronted, and which, with every passing moment, gains in urgency: the place and position of the media in this moment of fateful decision for the whole nation. For, there is no repression of people without the unleashing of monstrous propaganda and organized lying to buttress the rule of impunity. No mass violation of human rights can occur without ideological incitement! This is the road to self-destruction, from which there is no return ...

Saludos!

Suzanne Oboler

\section{References}

Alfano, S. 2010. Arizona School Asks Artists to Lighten Face of Hispanic Student on Mural. 4 June, http://www.nydailynews.com/news/national/2010/06/04/2010-0604_arizona_ school_asks_artists_to_lighten_face_of_hispanic_student_on_mural.html\#ixzz0qH5h4Bj8, accessed 8 June 2010. 
Cooper, J.J. 2010. Arizona Ethnic Studies Law Signed By Governor Brewer, Condemned By UN Human Rights Experts, Associated Press. 11 May, http://www.huffingtonpost .com/2010/05/12/arizona-ethnic-studies-la_n_572864.html, accessed 9 June 2010.

Frank, R.I., R. Akresh and B. Lu. 2010. June. Latino Immigrants and the US Racial Order: How and Where Do They Fit in? American Sociological Review 75(3): 378-401.

Morones, E. 2010. Todos Somos Sergio Adrian Hernández! This Hernández was only 14 years old! Shot and killed by Border Patrol. Border Angels Update (e-mail communication, 6 August 2010).

Oboler, S. 2007. The Value of Visibility and the Value of Truth. Latino Studies 5: 153-156.

Pew Hispanic Center. 2010. Hispanics and Arizona's New Immigration Law. Factsheet. 29 April, http://pewhispanic.org/factsheets/factsheet.php?FactsheetID=68, accessed 8 June 2010.

Rodríguez, R.C. 2010. Welcome to Apartheid, Arizona, USA. Column of the Americas. 15 May, http://web.me.com/columnoftheamericas/Site/ColumnoftheAmericas/Entries/ 2010/5/15_Welcome_to_Apartheid\%2C_Arizona\%2C_USA.html, accessed 7 June 2010.

Treviño, M. 2010. Latina Lista. 1 June, http://www.latinalista.net/palabrafinal/2010/06/ for_latinos_being_white_is_more_of_a_sta.html, accessed 6 June 2010.

Suzanne Oboler

John Jay College of Criminal Justice, City University of New York, New York

E-mail: soboler@jjay.cuny.edu 